\title{
Special issue on The evolution of writing systems
}

https://doi.org/10.1515/zfs-2021-2049

This issue is the second special issue of Zeitschrift für Sprachwissenschaft to be published exclusively online, as a third issue complementing this year's two regular issues. ZS online-only issues are meant to offer a forum for one of the AGs (workshops) that are part of the annual conference of the Deutsche Gesellschaft für Sprachwissenschaft (DGfS, the Linguistic Society of Germany) to publish selected contributions of their AG. The present issue has emerged from the Workshop The Evolution of Writing Systems: Empirical and Cross-Linguistic Approaches, organized by the guest editors Jessica Nowak, Lisa Dücker, Stefan Hartmann, and Renata Szczepaniak and held at the 42nd Annual Conference in Hamburg, in March 2020.

Pia Bergmann, Nicole Dehé, Gerhard Jäger,

Dejan Matić, and Natascha Pomino

Editorial staff of the Zeitschrift für Sprachwissenschaft 